\title{
Dairy Products Consumption Pattern and Consumers' Perception of Milk from Small Ruminants in Iwajowa Local Government Area of Oyo State
}

\section{Adeosun, Ayodele}

\author{
Animal Science Unit, Agricultural Education Department, College of Education, Lanlate
}

ARTICLE INFO

Article No.: 061118081

Type: Research

DOI: 10.15580/GJAS.2018.11.061118081

Submitted: $11 / 06 / 2018$

Accepted: 22/06/2018

Published: 03/12/2018

${ }^{\star}$ Corresponding Author

Adeosun Ayodele

E-mail: ayoadeosun2020@

gmail.com

Keywords: Dairy products, consumption pattern, perception, milk, small ruminants
ABSTRACT

A survey was carried out using structured questionnaire and personal interview to characterize the consumption pattern of milk and milk products and to identify factors affecting consumption in Iwajowa Local Government Area of Oyo State. A multistage sampling method was used to select eighty respondents. Data collected were analysed using percentages and simple means. Results from the study showed that majority $(52.5 \%)$ of the respondents were male with most $(47.5 \%)$ of the respondents within the age bracket of 21 and 30 . Moreover, $(47.5 \%)$ were single with most (51.25\%) belonging to family size of between 1 and 5 . Considering the occupation of the respondents, most $(35 \%)$ of the respondents were farmers. Religious affiliations showed that majority $(43.8 \%)$ practice Islam. The results also showed that respondents in the study area preferred cow milk to milk from small ruminants, though goat milk was preferred to sheep milk as far as ruminants are concerned. Factors such as taste, availability, price, considered nutritional factor and willingness of consumers to consume milk and milk products were observed to affect milk and milk products' consumption. About $62.5 \%$ of the respondents will accept milk from small ruminants while only about $68.75 \%$ of the respondents are willing to pay good market price of milk from small ruminants in the study area. Most $(52.5 \%)$ of the respondents believe that milk from small ruminants are richer in nutrients than milk from cow while most $(83.75 \%)$ of the respondents agreed that milk from small ruminants can be a source of income generation. The study recommends creation of more awareness on nutritional value, scanty availability of milk from small ruminants and addressing people's attitude/orientation toward milk from small ruminants. 


\section{INTRODUCTION}

Milk is a nearly white liquid, secreted by mammary glands of female mammals for nourishing their young. According to data gathered by the International Farm Comparison Network (IFCN) in 2005, around 149 million farm households throughout the world were engaged in milk production (FAO, 2010). Milk production is an important livestock-sector activity. According to Food and Agriculture Organisation (2001), dairy cattle produce about $84.6 \%(494,600 \mathrm{~L})$ of the world's milk against $2.1 \%$ $(12,500 \mathrm{~L})$ by goats and $1.3 \%(7,800 \mathrm{~L})$ by sheep. This productivity is strongly related to the body size and physiological characteristics of the dairy cattle in relation to that of sheep and goats, which of course give the former an added advantage of producing higher quantity of milk. Hence, the dairy (milk) industry depends heavily on dairy cattle as the main source of raw-milk for production of milk and other by-products for man's consumption.

To this end, dairy products have a unique contribution to nutritional status as well as health status of the smallholder household members. More so, Milk is said to be the most complete food item because of its biological value as it contains a variety of nutrients that help make it nature's most nearly perfect food. Although, milk is a naturally occurring and universal food for young mammals, it is consumed beyond infancy, especially in humans. So, man at different ages find milk consumption essential in the processed form as pastuerised milk (Adewumi, Ologun and Alokan 2007). Milk is obtained from cows, sheep and goats, buffaloes, camels etc. (Ochepo and Momoh, 2010) but the most dominant milk is that from cow. Dairy sheep and goats, though, do not produce much milk as dairy cattle, their milk is believed to be richer in nutrients and of better quality, and has more beneficial health properties than that of cattle (Ceballos et al. 2009). It is more nourishing and digestible than that of cattle, and as such recommended (pasreurished goat milk) for children's consumption on the ground that its protein nature is similar to that of human milk (Anisman-Reiner, 2007). Elwood, Pickering and Fehily, (2007) equally indicated that the conjugated linoleic acid (CLA) in small-ruminants' milk is cancerfighting and could improve insulin action and reduce blood glucose level in humans. Furthermore, goat milk could help to prevent disease such as anaemia and bone demineralization and also help with digestive and metabolic utilization of minerals such as iron, calcium, phosphorus and magnesium (Elwood et al. 2007)

Although, the reared small ruminants are dominantly local breeds, the animals have been observed to have the capacity of producing as much as $281.98 \mathrm{ml}$ per day following parturition (Bemji et al. 2007, Adewumi and Olorunisomo, 2009) and this can be increased by $58-78 \%$ on administration of bovine somatotorpin after the peak lactation which mostly take place at the third week of lactation. Though still underdeveloped, the dairy industry in Nigeria is dynamic with so many efforts been put forward to develop it. Dairy products in the Nigerian market are sourced locally and internationally. The major local dairy products in the market include Nunu (sour milk), Kindrimo (sour yoghurt), Cuku (Fulani cheese) and Wara (Yoruba cheese). The imported types are reported in official trace statistics come as sweetened (not concentrated) and unsweetened (concentrated) milk and cream; milk and cream in solid forms; butter, butter milk, cheese and curd. Products made with goat or sheep milk have some different and interesting characteristics especially taste, aroma, appearance and chemical constituents compared to the counterpart made with cow milk. Therefore, the objectives of this study were to assess pattern of dairy product consumption and examine consumers' perception of milk from small ruminant in the study area.

\section{METHODOLOGY}

\section{Study area}

This research work was carried out in Iwajowa Local Government Area of Oyo State between April, 2016 and August, 2016. It falls within latitude $X^{0} Y N$ and longitude $Z^{0}$ M'E. The Local Government area consists of a number of towns with villages. It is bounded in the West by Benin Republic, in the East by Kajola Local Government, in the North by Atisbo Local Government and bounded in the South by Ibarapa North Local Government. Iwere-ile is the headquarters of Iwajowa Local Government while other villages and settlements include; Iganna, Idiko-ile, Idi-Agemo, Ijeomeso, AyetoroIle, ljio, Itasa, Ilaja-ile, Elekokan, Ofeegun, Tudi, Jokolo and Ayegun Wasinmin. It has an area of $2,529 \mathrm{~km}^{2}$ and a population of 102,980 at the 2006 census.

\section{Research instruments}

The instruments used for this study were structured questionnaire and on-spot interview schedule. The questionnaire was divided into three sections, the demographic characteristics of the respondents such as age, sex, marital status, family size, occupation and religion. The other sections involve milk and milk products' consumption pattern, level of preference of milk and milk products perception of consumers as well as factors affecting consumption of small ruminant milk in the study area. 


\begin{tabular}{lccc}
\hline Responses & Value & Lower limit & Upper limit \\
\hline Very Important & 4 & 3.5 & 4.49 \\
Important & 3 & 2.5 & 3.49 \\
Slightly Important & 2 & 1.5 & 2.49 \\
Not Important & 1 & 0.5 & 1.49 \\
\hline
\end{tabular}

\section{Method of data collection}

A multistage sampling procedure was adopted in selecting the respondents. First, the random selection of five towns. Secondly, the random selection of sixteen households and lastly, the selection of one representative each of the households. The essence of the research was explained to the respondents in order to allay fear. They were also allowed to ask questions in the areas deemed ambiguous. Data collected were analysed using percentages and simple means. Likert scale was later used to rank some of the responses.

\section{Survey Detail}

The survey was conducted in the five communities namely Iganna, Iwere-Ile, Itasa, Elekokan and AyetoroIle. The selected respondents were given questionnaire to be administered and were later interviewed in order to enquire of them their acceptability and consumption of milk from small ruminants. Factors affecting the acceptability of milk from small ruminants were another interest of this paper. Their views about milk from small ruminants was also enquired of them. The frequencies obtained regarding these were converted to percentages.

\section{Method of data analysis}

The data in this research were subjected to percentage distribution and simple mean calculated from likert scale. The likert scale was used to rank the responses.

\section{RESULTS AND DISCUSSIONS}

Table 1 shows the demographic characteristics of the respondents. From the table, majority $(52.5 \%)$ of the respondents were males while $47.5 \%$ were females. Age distribution reveals that majority $(47.5 \%)$ of the respondents were within the age bracket of 21 and 30 followed by age bracket of 31 and 40 while above 40 was the least of the respondent. Analysis of respondents based on marital status indicated that majority (47.5\%) were single while $37.5 \%$ were married. Family size shows that most $(51.25 \%)$ have family size of between 1 and 5 followed by family size of $6-10(28.8 \%)$ of the respondents. Family size of above 15 was the least with
$7.5 \%$. Considering the occupation of the respondents, most $(35 \%)$ of the respondents were farmers followed by civil servants $(26.3 \%)$ with only $20 \%$ being artisans while $18.8 \%$ of the respondents were traders. Religious affiliations show that majority $(43.8 \%)$ practice Islam, $41.3 \%$ practice Christianity while $15 \%$ were traditional worshippers.

Table 1: Demographic characteristics of the respondents

\begin{tabular}{|c|c|c|}
\hline & Frequency & Percentage \\
\hline \multicolumn{3}{|l|}{ Sex } \\
\hline Male & 42 & 52.50 \\
\hline Female & 38 & 47.50 \\
\hline \multicolumn{3}{|l|}{ Age (Yrs) } \\
\hline Below 20 & 15 & 18.75 \\
\hline $21-30$ & 38 & 47.50 \\
\hline $31-40$ & 20 & 25.00 \\
\hline Above 40 & 7 & 8.75 \\
\hline \multicolumn{3}{|c|}{ Marital Status } \\
\hline Married & 30 & 37.50 \\
\hline Single & 38 & 47.50 \\
\hline Widow & 8 & 10.00 \\
\hline Divorced & 4 & 5.00 \\
\hline \multicolumn{3}{|l|}{ Family Size } \\
\hline $1-5$ & 41 & 51.25 \\
\hline $6-10$ & 23 & 28.75 \\
\hline $11-15$ & 10 & 12.50 \\
\hline Above 15 & 6 & 7.50 \\
\hline \multicolumn{3}{|l|}{ Occupation } \\
\hline Civil servant & 21 & 26.25 \\
\hline farming & 28 & 35.00 \\
\hline Artisan & 16 & 20.00 \\
\hline Trading & 15 & 18.75 \\
\hline \multicolumn{3}{|l|}{ Religion } \\
\hline Christianity & 33 & 41.25 \\
\hline Islam & 35 & 43.75 \\
\hline Traditional & 12 & 15.00 \\
\hline
\end{tabular}


Table 2 shows pattern of milk and milk products' consumption by the respondents. From the table, majority $(38.75 \%)$ of the respondents consumed fresh milk followed by powder milk $(32.5 \%)$ while the least consumed was evaporated milk (10\%). Furthermore, most $(30 \%)$ of the respondents consumed milk on a biweekly basis followed by $26.25 \%$ of the respondents who consumed milk on weekly basis. About $20 \%$ of the respondents consumed milk on daily basis, $13.75 \%$ consumed milk when the need arised, while $10 \%$ of them consumed milk on monthly basis. In the case of milk products' consumption, the table also reveals that majority $(41.25 \%)$ of the respondents consumed milk product in the form of Nunu, $25 \%$ consumed cheese milk product (wara) while $17.5 \%$ and $16.25 \%$ of the respondents consumed yoghurt and butter respectively. Frequency of milk products consumption from the table reveals that majority $(31.25 \%)$ of the respondents consumed their products Bi-weekly followed by $26.25 \%$ consuming the product on weekly basis. About $16.25 \%$ of the respondents each consume their product daily and monthly, while only $10 \%$ consume their product as need arises.

Table 2: Pattern of dairy and dairy products' consumption in the study area

\begin{tabular}{lcclcc}
\hline & Frequency & Percentage & & Frequency & Percentage \\
\hline Milk form & & & Milk Product form & & \\
Fresh milk & 31 & 38.75 & Butter & 13 & 16.25 \\
Pasteurized milk & 15 & 18.75 & Cheese & 20 & 25.00 \\
Evaporated milk & 8 & 10.00 & Nunu & 33 & 41.25 \\
Powder Milk & 26 & 32.50 & Yoghurt & 14 & 17.50 \\
Frequency of consumption & & & Frequency of consumption & & \\
As the need arise & 11 & 13.75 & As the need arise & 8 & 10.00 \\
Bi-weekly & 24 & 30.00 & Bi-weekly & 25 & 31.25 \\
Daily & 16 & 20.00 & Daily & 13 & 16.25 \\
Monthly & 8 & 10.00 & Monthly & 13 & 16.25 \\
Weekly & 21 & 26.25 & Weekly & 21 & 26.25 \\
\hline
\end{tabular}

Source: Field Survey, 2016

Table 3 shows factors affecting milk and milk products' consumption in the study area. From the table, the mean of all the factors are above the critical mean value of 2.5 , this implies that all the factors are very important factors that affect milk and milk products' consumption within the study area. However, when the means were used to rank the order of importance of these factors, taste was ranked first with a mean of 3.41 while willingness of consumers to consume milk and milk products' was ranked the least with a mean of 2.58. Other factors affecting milk and milk products' consumption are availability of milk and milk products, price of milk and milk products and considered nutritional factor. This result is in line with Ruel et.al. (2005) who observed that while factors such as income, prices and availability affect what consumers are able to purchase or consume, consumer preferences, on the other hand, shape the decisions that consumers make regarding what they choose to purchase or consume.

Table 3: Factors affecting milk and milk product consumption in the study area

\begin{tabular}{|c|c|c|c|c|c|c|}
\hline & VI & $\mathbf{I}$ & SI & NI & Mean & Rank \\
\hline Taste & 47 & 22 & 8 & 3 & 3.41 & $1 \mathrm{st}$ \\
\hline Availability of milk and milk products & 32 & 35 & 7 & 6 & 3.16 & $2 n d$ \\
\hline Price of milk and milk products & 18 & 46 & 16 & 0 & 3.03 & 3rd \\
\hline Nutritional factor & 34 & 15 & 25 & 6 & 2.96 & 4th \\
\hline Cleanliness of the milk/milk products & 29 & 26 & 11 & 14 & 2.88 & 5th \\
\hline Perceived odour & 20 & 37 & 13 & 10 & 2.84 & 6th \\
\hline Willingness to consume the milk/milk products & 17 & 28 & 19 & 16 & 2.58 & 7th \\
\hline
\end{tabular}

$\mathrm{VI}=$ Very Important, I=Important, SI= Slightly Important and $\mathrm{NI}=$ Not Important

Source: Field Survey, 2016 
Table 4 shows milk consumption preference. From the table, only means of cow milk and goat milk exceed the critical mean of 2.5, the mean (3.51, Std 0.46) as calculated, showed that respondents in the study area prefers cow milk to milk from small ruminants. Although, they still prefer goat milk with mean of 2.62 to that of sheep. Lastly, the respondents will not consume sheep milk since it had a mean of 2.26, a mean below the critical mean of 2.5. Although, consumption of milk from small ruminants can be improved through improved awareness and increased production of such milk.

Table 4: Distribution of respondents on Milk consumption preference

\begin{tabular}{lcccccc}
\hline & SA & A & D & SD & Mean & STD \\
\hline Cow milk & $46(56.5 \%)$ & $30(37.50 \%)$ & $2(2.50 \%)$ & $2(2.50 \%)$ & 3.51 & 0.46 \\
Goat milk & $9(11.25 \%)$ & $37(46.25 \%)$ & $28(35.00 \%)$ & $6(7.50 \%)$ & 2.62 & 0.62 \\
Sheep milk & $5(6.25 \%)$ & $24(30.00 \%)$ & $37(46.25 \%)$ & $14(17.5 \%)$ & 2.26 & 0.67 \\
\hline \multicolumn{7}{c}{ SA=Strongly Agree, A=Agree, D=Disagree, SD=Strongly Disagree }
\end{tabular}

Table 5 shows household distribution by their attitude to milk from small ruminants. From the table, $51.25 \%$ of the respondent was aware of the nutritional value of milk from small ruminants. Ceballos et al. (2009) reported that goat milk have unique nutritive properties which distinguishes it from cow, about $62.5 \%$ of the respondents were observed to accept milk from small ruminants. Only about $68.75 \%$ of the respondents are willing to pay market price of milk from small ruminants in the study area. In case income increases, majority $(65 \%)$ of the respondents will consume more of milk from small ruminants. Most $(85 \%)$ of the respondents have close substitute milk (cow) they consume instead of milk from small ruminants. Most $(52.5 \%)$ of the respondents believe that milk from small ruminants are richer in nutrients than milk from cow while most $(83.75 \%)$ of the respondents agreed that milk from small ruminants can be a source of income generation.

Table 5: Distribution of Households by their Attitude to milk from Small Ruminants Consumption

\begin{tabular}{|c|c|c|}
\hline & Frequency & Percentage \\
\hline \multicolumn{3}{|c|}{ Are you aware of nutritional value of milk from small ruminants } \\
\hline Yes & 41 & 51.25 \\
\hline No & 39 & 48.75 \\
\hline \multicolumn{3}{|c|}{ Will you accept milk from small ruminants for consumption } \\
\hline Yes & 50 & 62.50 \\
\hline No & 30 & 37.50 \\
\hline \multicolumn{3}{|c|}{ Are you willing to pay the market price of milk from small ruminant when available } \\
\hline Yes & 55 & 68.75 \\
\hline No & 25 & 31.25 \\
\hline \multicolumn{3}{|c|}{ In case your income increases will you consume more of milk from small ruminant } \\
\hline Yes & 52 & 65.00 \\
\hline No & 28 & 35.00 \\
\hline \multicolumn{3}{|c|}{ Do you have any close substitute you do use instead of milk from small ruminant } \\
\hline Yes & 68 & 85.00 \\
\hline No & 12 & 15.00 \\
\hline \multicolumn{3}{|c|}{ Milk from small ruminants are richer in nutrients than that of cow } \\
\hline Yes & 42 & 52.50 \\
\hline No & 38 & 47.50 \\
\hline \multicolumn{3}{|c|}{ Milk from small ruminants can be source of income generation } \\
\hline Yes & 67 & 83.75 \\
\hline No & 13 & 16.25 \\
\hline
\end{tabular}


Table 6 shows factors affecting acceptability of milk from small ruminants in the study area. From the table, most important factor affecting acceptability of milk from small ruminant is the awareness of the nutritive value of milk from small ruminant with mean 3.32 followed by perceived odour of the milk from small ruminant with a mean of 3.17. This work is in line with that of Apata and Adewumi (2011) who pointed out that goat and sheep odour was one of the factors militating against the consumption of goat and sheep milk. Acceptability is also determined by the taste of the milk with a mean of 2.91. Availability is another factor, ranked 4 as factor affecting consumption of milk from small ruminant according to the respondents; this might be because sheep and goat rearing are hardly raised for milk but largely for meat production and income generation in Southwest Nigeria as observed by Lawal-Adebowale (2012). Attitude of people towards milk from small ruminants was ranked 5th with a mean of 2.65. Taboo was not seen as a factor affecting acceptability of milk from small ruminants because it has a mean below the critical mean of 2.5. This shows that there was no taboo against milk from small ruminants.

Table 6: Factors affecting acceptability of milk from small ruminants

\begin{tabular}{|c|c|c|c|c|c|c|c|}
\hline & VI & $\mathbf{I}$ & SI & NI & Mean & STD & Decision \\
\hline Awareness of the nutritive value & $38(47.5)$ & $30(37.5)$ & $11(13.75)$ & $1(1.25)$ & 3.32 & 0.6 & Important \\
\hline Perceived odour & $32(40)$ & $35(43.75)$ & $7(8.75)$ & $6(7.5)$ & 3.17 & 0.8 & Important \\
\hline $\begin{array}{l}\text { ruminant } \\
\text { Availability of milk from small }\end{array}$ & $31(38.75)$ & $17(21.25)$ & $25(31.25)$ & $7(8.75)$ & 2.91 & 1.1 & Important \\
\hline ruminant & $21(26.25)$ & $25(31.25)$ & $19(23.75)$ & $15(18.75)$ & 2.89 & 1.1 & Important \\
\hline $\begin{array}{l}\text { Attitude of people to milk from } \\
\text { small ruminant }\end{array}$ & $22(27.5)$ & $25(31.25)$ & $16(20)$ & $17(21.25)$ & 2.65 & 1.2 & $\begin{array}{l}\text { Important } \\
\text { Slightly }\end{array}$ \\
\hline Taboo & $13(16.25)$ & $25(31.25)$ & $20(25)$ & 22(27.5) & 2.37 & 1.1 & Important \\
\hline
\end{tabular}

$\mathrm{VI}=$ Very important, $\mathrm{I}=\mathrm{Important}, \mathrm{SI}=$ Slightly important and $\mathrm{NI}=$ Not important

\section{CONCLUSION AND RECOMMENDATIONS}

The results of this study showed that respondents in the study area preferred cow milk to milk from small ruminants although, they still prefer goat milk to sheep milk among ruminants. It was observed that factors such as taste, availability, price, considered nutritional factors and willingness of consumers to consume milk and milk products were considered to affect milk and milk products' consumption. Most of the respondents were eager to accept milk from small ruminants with many of the respondents willing to pay market price of milk from small ruminants in the study area. Most of the respondents believed that milk from small ruminants is richer in nutrients than milk from cow. The respondents also agreed that milk from small ruminants can be a source of income generation.

\section{Recommendations}

Based on the results of this paper, the following recommendations were made: there should be improved programmes to raise awareness of consumers about milk from small ruminants. Perceived odour of milk from small ruminants can be improved through improving management of small ruminants by rearing and milking animals in a hygienic environment. In the case of availability of milk from small ruminants, farmers should be encouraged to make more milk from small ruminants available to consumers. Lastly, the attitude of consumer/ orientation toward milk from small ruminants should be addressed by availing more information about the nutritional values of milk from small ruminants. These recommendations might increase consumers consumption of milk from small ruminants, help raise income levels and ensure better health status of households in the study area.

\section{REFERENCES}

Adewumi, O.O., Ologun, A.G. and Alokan, A.J. (2001). Sensory evaluation and marketability of sheep milk in Akure. J. Agric. for Fish. 2:5-7

Adewumi,O.O. and Olorunisomo, O. (2009). Milk yield and milk composition of Yankasa, West African Dwarf sheep and their crossbreed sheep in South West of Nigeria. Livestock Research fot Rural Development, Colombia. . pp 1-7.

Anisma-Reiner, V. (2007). Cow's milk vs. Goat's milkDairy Allergies, Lactose intolerance, mucus, acidity and Hormones.

Apata, O.M. and Adewumi, O.O. (2011). Perception of sheep and goat milk consumption among rural 
dwellers in South Western Nigeria. Niger. J. Anim. Prod. 38:145-152.

Bemji, M.N., Osinowo, O.A., Ozoje, M.O., Adebambo, O.A. and Aina, A.B.J. (2007). A comparative study on milk yield and pre-weaning growth of West African Dwarf and Red Sokoto goats intensively managed in South West Nigeria. Ghana J. Anim. Sci. 2, 3 (1) 81-88.

Caballos, L.S., Morales, E.R., Adarve, G.T., Castro, J.D., Martinez, L.P. ans Sampelayo, M.R.S. (2009). Consumption of cow and goat milk produced under similar conditions and analysed by identical methodology. J. Food Compos. Anal. 22: 322-329.

Elwood, P.C., Pickering, J.E. and Fehily, A.M. (2007). Milk and Dairy consumption, diabetes and metabolic syndrome: the aephilly prospective study. $J$. Epidemiol. Community Health. 61 (8) 695-8.
FAO (2001). Production yearbook 1999. Food and Agriculture Organisation of United Nations, Vol. 53, Statistical series No. 156: 251-253, Rome, Italy.

FAO 2010: Status of and Prospects for Smallholder Milk Production - A Global Perspective, by T. Hemme and J. Otte. Rome.

Lawal-Adebowale, O.A. (2012). Factors influencing small ruminant management in selected urban communities of Abeokuta, Ogun State. Niger. J. Anim. Prod. 39(1): 218-228.

Ruel, M.T., Minot, N. and Smith, L. (2005). Pattern and determinants of fruit and vegetable consumption in Sub-Saharan Africa: a multicountry comparison. Background paper for the joint FAO/WHO workshop on fruits and vegetables for health. 1-3 September 2004, Kobe, Japan. 